\title{
GEOGRAPHIC VARIATION AND GENETIC STRUCTURE IN THE STREAK-BACKED ORIOLE: LOW MITOCHONDRIAL DNA DIFFERENTIATION REVEALS RECENT DIVERGENCE
}

\author{
Nandadevi Cortes-Rodríguez ${ }^{1,2,3}$, Blanca E. Hernández-Baños ${ }^{1}$, \\ Adolfo G. Navarro-Sigüenza ${ }^{1}$, and Kevin E. Omland ${ }^{2}$ \\ ${ }^{1}$ Museo de Zoología “Alfonso L. Herrera,”' Departamento de Biología Evolutiva, Facultad de Ciencias, Universidad Nacional \\ Autónoma de México, Apartado Postal 70-399, D.F. 04510, Mexico \\ ${ }^{2}$ Department of Biological Sciences, University of Maryland Baltimore County, 1000 Hilltop Circle, Baltimore, MD 21250
}

\begin{abstract}
Many avian species from the temperate zone show low levels of genetic diversity when compared with species from the tropics, although there are some interesting exceptions, and species whose ranges occur across the temperate-tropical boundary could have characteristics of either or both zones. The distribution of the Streak-backed Oriole (Icterus pustulatus) extends from northwestern Sonora in Mexico south along the Pacific coast to Costa Rica. In addition, there is a population on the Tres Marías Islands. Northern populations are migratory and dichromatic (sexes different), whereas southern populations are nonmigratory and monochromatic (sexes alike). We sequenced mtDNA (control region domain I) from 102 individuals across the range of this species. Maximum parsimony and maximum likelihood analyses did not support the existence of multiple species within Icterus pustulatus based on mtDNA. However, populations from the Tres Marías Islands seem to have been isolated long enough to have fixed differences from populations on the mainland. The species complex shows an uncommon phylogeographic pattern, with shallow haplotype trees and weak geographic structure, suggesting that it has undergone recent population expansion. We recommend that the insular populations be considered a separate species, Icterus graysonii, given the fixed differences from mainland birds in multiple characteristics, including mtDNA and plumage patterns.
\end{abstract}

Key words: Icterus pustulatus, mitochondrial DNA, phylogeography, population genetics, speciation.

Variación Geográfica y Estructura Genética de Icterus pustulatus: Poca Diferenciación en el DNA mitocondrial Revela una Divergencia Reciente

Resumen. Muchas especies de aves de zonas templadas muestran niveles bajos de diferenciación genética en comparación con especies de las zonas tropicales. Sin embargo, hay algunas excepciones interesantes y especies cuyos rangos de distribución se encuentran a través del límite tropical-templado podrían tener características de cualquiera o ambas zonas. La distribución de Icterus pustulatus va de Sonora en el noroeste de México, al sur a lo largo de la costa del pacífico hasta Costa Rica. Además, existe una población en las islas de Tres Marías. Las poblaciones norteñas son migratorias y dicromáticas (sexos diferentes), mientras que las poblaciones sureñas no son migratorias y monocromáticas (sexos iguales). Se secuencio el primer dominio de la Región Control (DNA mitocondrial) para un total de 102 individuos a lo largo de su distribución. Los análisis de parsimonia y de máxima verosimilitud no apoyaron la existencia de más de una especie al interior del complejo Icterus pustulatus, sin embargo, las poblaciones de las islas de Tres Marías pudieran haber estado aisladas por un período bastante largo para acumular diferencias fijadas entre las islas y el continente. El complejo presenta un patrón filogeográfico poco común, con árboles que muestran baja resolución y una estructura geográfica débil, sugiriendo que la especie ha experimentado una reciente expansión poblacional. Recomendamos que las poblaciones insulares se consideren como una especie separada, Icterus graysonii, debido las diferencias fijas que la diferencian de los individuos del continente y utilizando múltiples caracteres incluyendo patrones del mtDNA y del plumaje.

\section{INTRODUCTION}

Many studies of geographic variation in temperate-zone birds have shown low levels of genetic variation (Ball et al. 1988, Milá et al. 2000, Baker et al. 2003, Kondo et al. 2004). In contrast, many tropical species show relatively high levels of variation in mitochondrial DNA (mtDNA; Peterson 1992, Hackett
1993, Bates et al. 1999, García-Moreno et al. 2004, Tobias et al. 2008; see also Weir and Schluter 2007). In many tropical species, molecular variation coincides with phenotypic variation, e.g., in the Common Bush-Tanager (Chlorospingus ophthalmicus; García-Moreno et al. 2004). However, there are exceptions to these general trends, and several temperate species also show marked genetic divergences that correspond

Manuscript received 15 February 2007; accepted 24 September 2008.

${ }^{3}$ E-mail: mcortes1@umbc.edu

The Condor, Vol. 110, Number 4, pages 729-739. ISSN 0010-5422, electronic ISSN 1938-5422. (C 2008 by The Cooper Ornithological Society. All rights reserved. Please direct all requests for permission to photocopy or reproduce article content through the University of California Press's Rights and Permissions website, http://www.ucpressjournals.com/ reprintInfo.asp. DOI: 10.1525/cond.2008.8578 
with morphology (Drovetski et al 2004, Spellman and Klicka 2007, Spellman et al. 2007). Other temperate species do not show substantial morphological variation, yet show deep molecular splits (e.g., Carolina Chickadee [Poecile carolinensis], Gill et al. 1999; Common Raven [Corvus corax], Omland et al. 2000). Furthermore, there are cases such as the Orchard Oriole group (Icterus spurius spurius vs. Icterus spurius fuertesi; Baker et al. 2003), in which morphology shows variation without differences in mtDNA. Further studies with intensive geographic sampling are needed to test for correspondence between genes and morphology in temperate versus tropical regions.

A well-known example of within-species geographic variation among Mexican birds is the Streak-backed Oriole (Icterus pustulatus) complex. This polytypic species has an extensive range, from Sonora in northwestern Mexico south along the Pacific coast to Costa Rica, as well as an insular population on the Tres Marías Islands (Friedmann et al. 1950, Howell and Webb 1995, AOU 1998, Jaramillo and Burke 1999). Thus, this species' range includes both tropical and temperate regions. Despite its generally continuous distribution, populations show differences in plumage coloration patterns and in morphometric traits. Northern temperate breeding populations (race microstictus) are winter migrants and are sexually dichromatic. Males are bright orange with a reddish-orange head, small black streaks on the back, and black wings with white edges; females are similar to males in pattern, but much duller and with the back, nape, and crown olive-green (Jaramillo and Burke 1999). Males from the Tres Marías Islands (race graysonii) tend to be a yellowish orange and usually lack the streaks on the back (or have only a few streaks on the scapulars), while females are similar but with a more olive coloration (Howell and Webb 1995, Jaramillo and Burke 1999). More southern tropical populations (El Salvador to Costa Rica, race sclateri) are not migratory and are monochromatic (sexes alike, both sexes elaborate). Additionally, in specimens from Guatemala to Honduras (race alticola), the streaking is much wider so that birds' backs are almost completely black (Miller and Griscom 1925).

The general plumage variation and some of the morphometric measurements reported by Jaramillo and Burke (1999) might show a general clinal pattern, since male specimens show more black coloration on their backs and females become more male-like farther south; in addition, southernmost specimens (sclateri and alticola) show longer wing measurements on average (although no rigorous morphometric analysis has been conducted). Specimens from the Tres Marías Islands are not substantially bigger; however, these populations show the largest average culmen measurements.

Given all this geographic variation, many authors (Table 1) have proposed that the Streak-backed Oriole is a superspecies composed of several groups or distinct species. Howell and Webb (1995) proposed four groups: microstictus (breeds from Sonora to Jalisco in Mexico), graysonii (resident in the Tres Marías Islands), pustulatus (including formosus, resident from Jalisco in Mexico to Honduras), and alticola (resident

TABLE 1. Summary of all the taxonomic proposals made for the Streak-backed Oriole (Icterus pustulatus) complex, since the description of the species. Three major proposals for species limits that we tested using mtDNA and AMOVA are marked with a dagger $\left({ }^{\dagger}\right)$.

\begin{tabular}{|c|c|}
\hline Reference & Main conclusions \\
\hline Wagler (1829) & Describes the Streak-backed Oriole (Icterus pustulatus) \\
\hline Cassin (1867) & Describes I. sclateri and I. graysonii (Tres Marías Islands) \\
\hline Lawrence (1872) & Describes Icterus formosus \\
\hline Ridgway (1911) & $\begin{array}{l}\text { Recognizes several species of Icterus, particularly I. pustulatus, I. sclateri, and I. graysonii. } \\
\text { Proposes that the specimens from Nicaragua should be treated as I. s. formosus }\end{array}$ \\
\hline Van Rossem (1927) & Proposes I. sclateri and I. pustulatus as conspecific \\
\hline Friedman et al. (1950) & $\begin{array}{l}\text { Recognize I. p. microstictus, I. p. graysonii, I. p. pustulatus, and I. p. formosus (southern } \\
\text { Mexico and northwestern Guatemala) }\end{array}$ \\
\hline Peters (1968) & $\begin{array}{l}\text { Recognizes I. p. microstictus from Sonora and Chihuahua to Jalisco and Guerrero, I. } p \text {. } \\
\text { graysonii from Tres Marías Islands (México), I. p. pustulatus from Colima to Guatemala, } \\
\text { I. p. formosus from southeast Mexico to northern Guatemala, I. p. alticola on the Atlantic } \\
\text { slope of Guatemala, and I. p. sclateri from Guatemala to Nicaragua }\end{array}$ \\
\hline Howell and Webb $(1995)^{\dagger}$ & $\begin{array}{l}\text { Recognize four groups: microstictus (breeds from Sonora to Jalisco), graysonii (Tres Marías } \\
\text { Islands), pustulatus (including formosus, breeds from Jalisco to Honduras), and alticola } \\
\text { (breeds in Costa Rica valley) }\end{array}$ \\
\hline Phillips (1995) & $\begin{array}{l}\text { Proposes three new forms: I. p. yaegeri (southern Sinaloa to southern Nayarit), I. p. dicker } \\
\quad \text { mani (southwestern Jalisco to southern Guerrero), and I. p. interior (central-south Mexico) }\end{array}$ \\
\hline AOU (1998) & Recognizes three groups: pustulatus, graysonii, and sclateri \\
\hline Jaramillo and Burke (1999) $)^{\dagger}$ & $\begin{array}{l}\text { Propose three groups: pustulatus (from Sonora to north Oaxaca), graysonii (from Tres } \\
\text { Marías Islands), and sclateri (from north Oaxaca to Costa Rica) }\end{array}$ \\
\hline Navarro-Sigüenza and Peterson $(2004)^{\dagger}$ & $\begin{array}{l}\text { Recognize three distinct species: I. sclateri (includes I. s. formosus) from Chiapas to } \\
\text { Honduras, I. pustulatus (includes I. p. microstictus) in Western Mexico from Sonora } \\
\text { to Chiapas, and I. graysonii on the Tres Marías Islands (Mexico) }\end{array}$ \\
\hline
\end{tabular}


in the interior valleys of Central America). Later, Jaramillo and Burke (1999) proposed three groups: pustulatus (from Sonora to northern Oaxaca in Mexico), graysonii (on the Tres Marías Islands), and sclateri (from southern Oaxaca and Chiapas in Mexico to Costa Rica). Recently, Navarro-Sigüenza and Peterson (2004) proposed full species status for the same groups as Jaramillo and Burke (1999); however, their proposed group boundaries are different. Navarro-Sigüenza and Peterson (2004) suggest that pustulatus occurs from Sonora to Chiapas in Mexico, sclateri occurs from Chiapas in Mexico to Honduras, and graysonii is found on the Tres Marías Islands. The AOU (1998) also recognizes the three groups proposed by Jaramillo and Burke (1999), although, again, the proposed boundaries between them are slightly different.

It is important to emphasize that even though these morphologically based species descriptions agree on the probable existence of more than one species within Icterus pustulatus, the boundaries between them are not clear. Also, no rigorous morphological or molecular study has been conducted. Therefore, we set out to accomplish several goals: (1) to determine if the degree of genetic variation among Streak-backed
Oriole populations corresponds to the degree of morphological variation, (2) to evaluate whether the recognition of multiple species would be supported by mtDNA, and (3) to report the overall patterns of genetic variation within and among populations of the Streak-backed Oriole complex. Our results give important insights into the evolutionary history and taxonomic status of this interesting temperate-tropical species.

\section{METHODS}

\section{LABORATORY PROCEDURES}

We obtained tissue samples (muscle, heart, and liver) from 102 individuals (Appendix) of the Streak-backed Oriole complex collected from across the species' range (38 localities; Fig. 1). We used the Bullock's Oriole (Icterus bullockii) and Baltimore Oriole (Icterus galbula) as outgroups for phylogenetic analyses (Omland et al. 1999, Allen and Omland 2003). DNA was extracted from tissue samples using the DNeasy Tissue Kit (Quiagen, Valencia, California). We amplified the mitochondrial control region (CR-Domain I) using two primers spanning 344 base pairs: LGL2 (CGCCACATCAGACAGTCCAT)

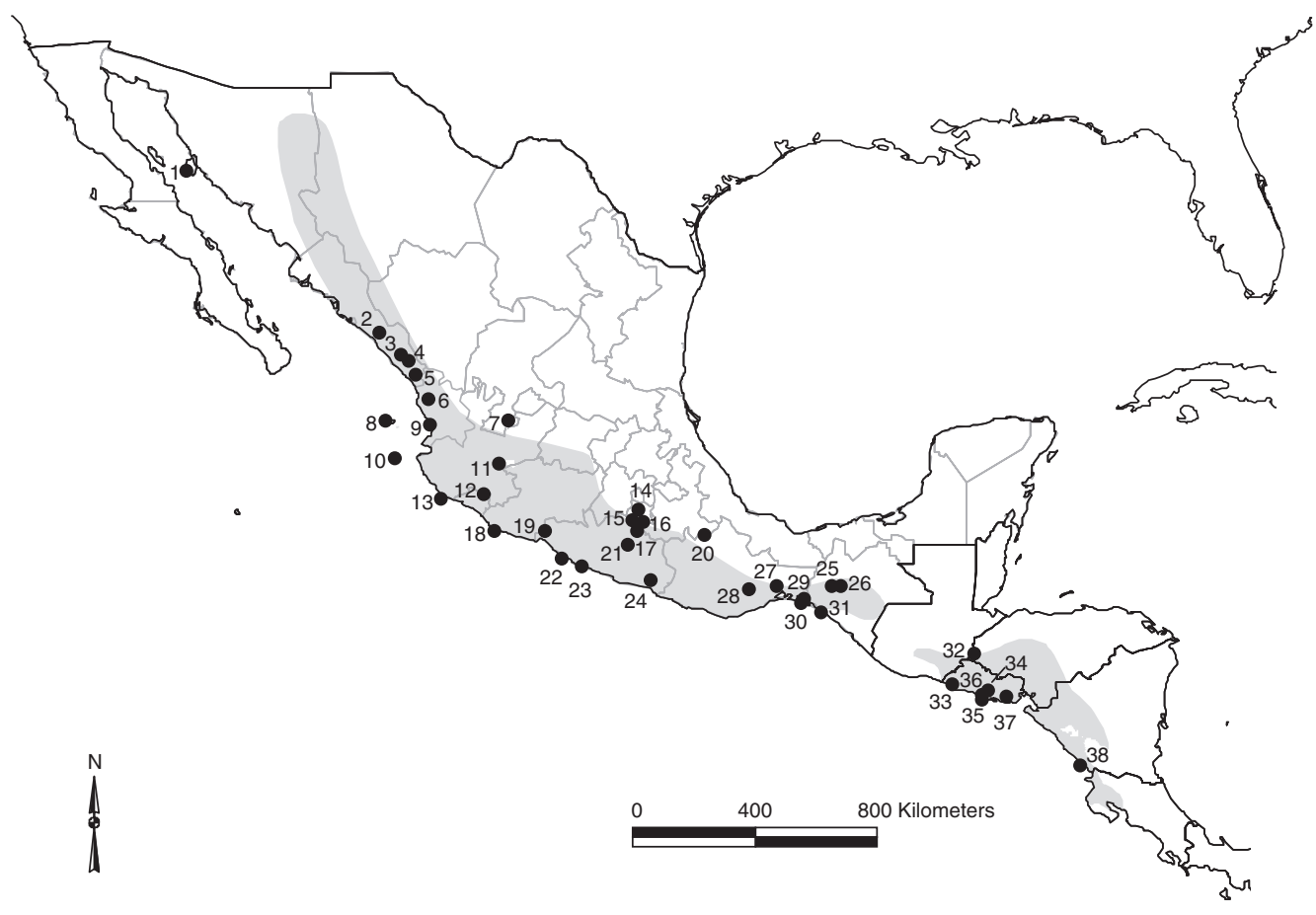

FIGURE 1. Map summarizing the approximate geographic range (gray shadow) of the Streak-backed Oriole (Icterus pustulatus), and sampling localities surveyed for this study (circles). Localities are: 1. Isla Tiburón, Sonora; 2. Cosalá, Sinaloa; 3. El Magistral, Sinaloa; 4. Copala, Sinaloa; 5. El Limón, Sinaloa; 6. Tierra Generosa, Nayarit; 7. Jalpa, Zacatecas; 8. Isla María Magdalena, Nayarit; 9. San Blas, Nayarit; 10. Isla Maria Madre, Nayarit; 11. Chapala, Jalisco; 12. Laguna la María, Colima; 13. Emiliano Zapata, Jalisco; 14. Yautepec, Morelos; 15. Puente de Ixtla, Morelos; 16. Limón, Morelos; 17. Huautla, Morelos; 18. Las Haciendas, Michoacán; 19. Presa Infiernillo, Michoacán; 20. Venta Salada, Puebla; 21. San Miguel Tecuiciapan, Guerrero; 22. Los Cirilos, Guerrero; 23. Laguna Nuxco, Guerrero; 24. El Carmen, Guerrero; 25. Ocozocuautla, Chiapas; 26. Tuxtla Gutierrez, Chiapas; 27. Nizanda, Oaxaca; 28. Cerro Piedra Larga, Oaxaca; 29. Rancho las Minas, Oaxaca; 30. San Pedro Tapanatepec, Oaxaca; 31. Rancho Bellavista, Chiapas; 32. Copán, Honduras; 33. Cruz Grande, El Salvador; 34. San Vicente, El Salvador; 35. Zacatecoluca, El Salvador; 36. Volcán San Miguel, El Salvador; 37. Cantón Animas Abajo, El Salvador; and 38. La Flor, Nicaragua. 
and H417 (CTCACGAGAACCGAGCTACT; Tarr 1995). A typical control region amplification involved an initial cycle of $4 \mathrm{~min}$ at $95^{\circ} \mathrm{C}, 1 \mathrm{~min}$ at $50^{\circ} \mathrm{C}$, and $45 \mathrm{sec}$ at $72^{\circ} \mathrm{C}$, followed by 35 cycles of $1 \mathrm{~min}$ at $95^{\circ} \mathrm{C}, 1 \mathrm{~min}$ at $50^{\circ} \mathrm{C}, 45 \mathrm{sec}$ at $72^{\circ} \mathrm{C}$, and a final elongation step of $10 \mathrm{~min}$ at $72^{\circ} \mathrm{C}$. PCR was carried out on the Gene Amp PCR System 9700 (Applied Biosystems, Foster City, California) and products were verified on a $1 \%$ agarose gel, revealed by staining ethidium bromide, and cleaned using QIAquick PCR purification kits (Qiagen). We sequenced these products using ABI's BigDye v.3 Terminator Cycle Sequencing Kit on the Gene Amp PCR system 2400 (Applied Biosystems). Excess dye terminators were removed by the EDTA-ethanol precipitation protocol recommended by Applied Biosystems, and sequences were run out on an ABI 3100 DNA sequencer (Applied Biosystems).

\section{PHYLOGENETIC ANALYSES}

Once we obtained the mtDNA sequences, we edited and aligned them using Sequencher 4.1 (Genecodes Corporation, Ann Arbor, Michigan). Maximum parsimony trees were constructed for the control region sequences using euristic searches in PAUP* (version 4.0b8; Swofford 1999). We conducted 1000 bootstrap pseudoreplications to determine support values for various nodes on the phylogenies. We tested for the nucleotide substitution model that best fit our data using Modeltest 3.7 (Posada and Crandall 1998). We then performed maximum likelihood analysis in PAUP* with a heuristic search of 1000 random additions. We also constructed a haplotype network using Network 4.1.1.2 (Bandelt et al. 1999; <www.fluxus-engineering.com>, MJ algorithm).

\section{POPULATION GENETIC ANALYSES}

We performed an analysis of molecular variance (AMOVA) to test which of the three major taxonomic proposals (Table 1) best fit the mtDNA (Howell and Webb 1995, Jaramillo and Burke 1999, Navarro-Sigüenza and Peterson 2004). We also conducted an additional AMOVA separating the northern populations into two groups: individuals from the Tres Marías Islands (graysonii group) versus individuals from the mainland. Significance values for the AMOVA took into account the number of mutations among haplotypes $(\Phi$-statistics) and were performed with 1000 permutations. We used mismatch distributions to determine whether the Streak-backed Oriole complex is in mutational-drift equilibrium or undergoing demographic expansion. These analyses were performed in Arlequin version 3.01 (Excoffier et al. 2005).

\section{RESULTS}

\section{SEQUENCE DATA}

Of the 344 base pairs of mtDNA sequence obtained from the control region, only 13 were variable $(3.8 \%)$ and eight were parsimony informative $(2.3 \%)$. We found a total of 16 haplotypes (Table 2). The most common haplotype (A1) was found

TABLE 2. MtDNA haplotypes and sampling sites of the Streak-backed Oriole (Icterus pustulatus) throughout its range. The numbers in parentheses correspond to the number of individuals in the population containing that specific haplotype.

\begin{tabular}{|c|c|c|}
\hline Haplotype & $\begin{array}{l}\text { No. of } \\
\text { individuals }\end{array}$ & Sampled state, locality, and number of samples \\
\hline A1 & 34 & $\begin{array}{l}\text { Chiapas: Rancho Bellavista (3), Tuxtla Gutierrez (2), Ocozocautla (2); Guerrero: El Carmen (3); Oaxaca: } \\
\text { San Pedro Tepanatepec (3), Nizanda (3), Cerro Piedra Larga (3); Morelos: Yautepec (1); El Salvador: } \\
\text { Cantón Cruz Grande (2), San Vicente (2), Cantón Animas Abajo (2) Volcán de San Miguel (1), } \\
\text { Zacatecoluca (2); Honduras: Cópán (5) }\end{array}$ \\
\hline A2 & 1 & Guerrero: Los Cirulos (1) \\
\hline A3 & 1 & Oaxaca: Cerro Piedra Larga (1) \\
\hline B1 & 29 & $\begin{array}{l}\text { Sonora: Isla Tiburón (1); Colima: Laguna la María (2); Jalisco: Emiliano Zapata (2), Chapala (2); } \\
\text { Michoacán: Presa Infiernillo (1), Las Haciendas (1); Nayarit: San Blas (4), Tierra Generosa } \\
\text { (1); Chiapas: Rancho Bellavista (1); Zacatecas: Jalpa (1); Puebla: Venta Salada (1); Sinaloa: Copala } \\
\text { (4), El Magistral(1), Cosálá (3), El Limón (4) }\end{array}$ \\
\hline B2 & 1 & Jalisco: Emiliano Zapata (1) \\
\hline B3 & 1 & Michoacan: Presa Infiernillo (1) \\
\hline B4 & 15 & Nayarit: Isla María Magdalena (6), Isla María Madre (2) \\
\hline B5 & 2 & Nayarit: San Blas (2) \\
\hline B6 & 1 & Sinaloa: Cosálá (1) \\
\hline B7 & 1 & Sinaloa: Cosálá (1) \\
\hline B8 & 1 & Sinaloa: El Limón (1) \\
\hline $\mathrm{C} 1$ & 14 & $\begin{array}{l}\text { Guerrero: San Miguel Tecuiciapan (5); Michoacán: Laguna Nuxco (1), Presa Infiernillo (2); Morelos: Puente } \\
\text { de Ixtla (1), Limon (1); Nicaragua: La Flor (1); Oaxaca: Cerro Piedra Larga (1); Puebla: Venta Salada (2) }\end{array}$ \\
\hline $\mathrm{C} 2$ & 3 & Guerrero: San Miguel Tecuiciapan (1); Morelos: Huautla (1), Yautepec (1) \\
\hline $\mathrm{C} 3$ & 2 & Guerrero: Los Cirulos (1); Michoacán: Presa Infiernillo (1) \\
\hline $\mathrm{C} 4$ & 2 & Morelos: Limon (2) \\
\hline $\mathrm{C} 5$ & 1 & Oaxaca: Cerro Piedra Larga (1) \\
\hline
\end{tabular}




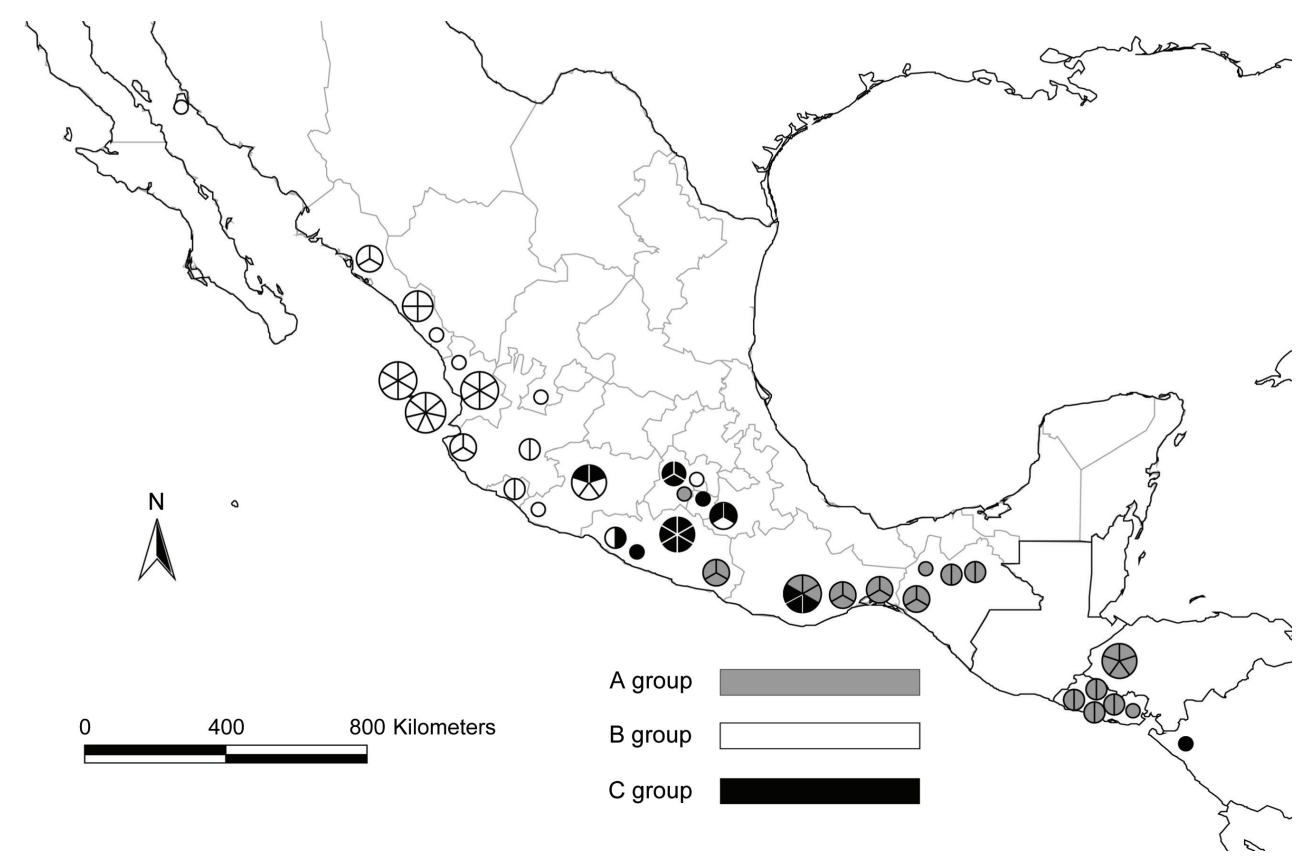

FIGURE 2. Map showing the distribution of the three major groups of mtDNA haplotypes of Streak-backed Orioles (Icterus pustulatus) found in this study. Most of the individuals from the north of Mexico belong to the B group, while most of the individuals in the south belong to the A group. Wedges inside each circle represent the number of individuals sampled from that specific locality.

predominantly in southern populations (15 populations from Guerrero, Morelos, Oaxaca, Chiapas, El Salvador, and Honduras). The second most common haplotype (B1) was generally found in northern populations (Sonora, Sinaloa, Zacatecas, Nayarit, Jalisco, Michoacan, Colima, Puebla, and Oaxaca). Haplotype $\mathrm{C} 1$ was generally restricted to birds from central Mexico, except for a single individual from Nicaragua. Individuals from the Tres Marías Islands all shared one unique haplotype (B4); there were no haplotypes shared between these islands and the mainland. However, on the mainland, haplotypes were roughly divided into three groups - one each in the north, south, and central parts of the range-although there were not strong geographic breaks between haplotype groups (Fig. 2). Haplotype diversity was greatest in central Mexico, especially in the states of Guerrero, Morelos, and Puebla. There were few differences among haplotypes, with only one base change separating most haplotypes. Nucleotide diversity $(\pi)$ for the whole species was $0.0041 \pm 0.0028$, while haplotype diversity (h) was $0.80 \pm 0.02$, with a maximum pairwise divergence of $1.7 \%$.

\section{NETWORKS AND TREES}

The median joining network (Fig. 3) showed the distribution of haplotypes and their relationships to geography. As mentioned previously, haplotype A1 was the most common. Haplotype B7 from Sinaloa appeared as an alternative connection between haplotype $\mathrm{B} 1$ and $\mathrm{C} 1$. The individuals from the Tres Marías Islands had a unique haplotype (B4); one fixed mutational step separated them from the common northern

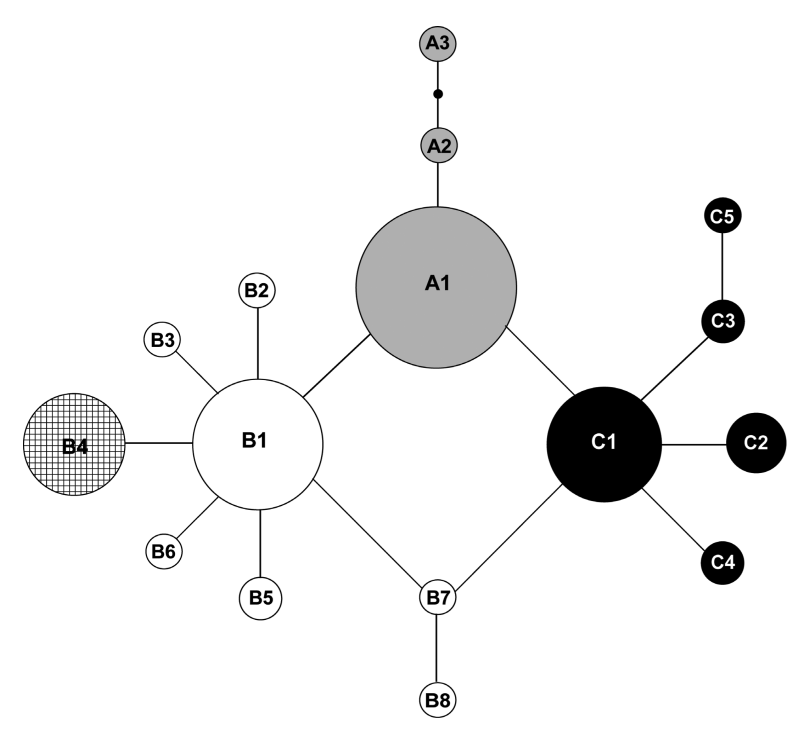

FIGURE 3. Haplotype median joining network of the Streakbacked Oriole (Icterus pustulatus) as computed in Networks 4.1.1.1 using mitochondrial DNA sequenced from individuals sampled throughout the species' range. The size of each circle is proportional to the number of individuals with that specific haplotype. Three different haplotype groups were distinguished: gray shaded circles represent haplotype group A, generally found in southern Mexico and Central America; white circles represent haplotype group B, found in northern and central Mexico; and black circles represent haplotype group C, generally found in central Mexico and with an outliner individual from Nicaragua. Text inside the circle represents each haplotype's unique designation. An unsampled haplotype is shown as a solid dot. Note the distinct Tres Marías Islands haplotype (B4). 
TABLE 3. Results of AMOVAs testing hypotheses regarding the Streak-backed Oriole (Icterus pustulatus) complex. We tested the hypothesis of Howell and Webb (1995), who proposed that populations were divided into four main groups, and an alternative hypothesis that populations were divided into two groups, one containing the Tres Marías Islands individuals, and the other containing mainland northern individuals.

\begin{tabular}{|c|c|c|c|c|c|}
\hline $\begin{array}{l}\text { Hypothesis } \\
\text { Source of variation }\end{array}$ & df & $\begin{array}{l}\text { Sum of } \\
\text { squares }\end{array}$ & $\begin{array}{c}\text { Variance } \\
\text { components }\end{array}$ & $\begin{array}{l}\text { Percent of } \\
\text { variation }\end{array}$ & $P$-value \\
\hline \multicolumn{6}{|l|}{ Howell and Webb (1995): $\Phi_{\mathrm{ST}}=0.75$} \\
\hline Among groups & 3 & 30.6 & 0.53 & 55.67 & $<0.001$ \\
\hline Among populations within groups & 34 & 24.3 & 0.18 & 18.75 & $<0.001$ \\
\hline Within populations & 64 & 15.8 & 0.24 & 25.58 & $<0.001$ \\
\hline Total & 101 & 70.7 & 0.96 & & \\
\hline \multicolumn{6}{|c|}{ Tres Marías Islands vs. mainland: $\Phi_{\mathrm{ST}}=0.68$} \\
\hline Among groups & 1 & 6.2 & 0.47 & 60.27 & $<0.001$ \\
\hline Among populations within groups & 9 & 3.7 & 0.06 & 7.57 & $<0.001$ \\
\hline Within populations & 21 & 5.3 & 0.25 & 32.15 & $<0.001$ \\
\hline Total & 31 & 15.2 & 0.79 & & \\
\hline
\end{tabular}

haplotype (B1). Each of the three most common haplotypes had a group of less-common haplotypes likely derived from it (e.g., B1 had B2 to B6).

The model of evolution that best fit our data according to Akaike's information criterion (AIC) was the HKY + I model, with the following parameter values: $\mathrm{A}=0.30, \mathrm{C}=0.30, \mathrm{G}$ $=0.16, \mathrm{~T}=0.22$, Ti:Tv ratio $=4.59$, and $\mathrm{I}=0.81$. Maximum likelihood searches produced only one tree (not shown) with $\mathrm{a}-\log (\mathrm{n})=679$, which showed the nonmonophyly of haplotypes within each of the geographic areas. The Tres Marías Islands appeared nested within the same group containing all northern samples.

We obtained six parsimonious trees of 32 steps, with a consistency index $=0.87$, retention index $=0.95$, and homoplasy index $=0.12$. A majority rule consensus was made for the six trees. We found three major groups, but we did not find support for the reciprocal monophyly of geographic areas, as many haplotypes were shared between populations in different regions.

\section{POPULATION GENETIC ANALYSES}

Of the three major taxonomic proposals that we tested, that of Howell and Webb (1995) explained the largest percentage of variation (56\%; Table 3$)$. Thus, the majority of variation was accounted for by among-group divergence (I. p. microstictus, I. p. pustulatus, I. p. graysonii, and I. p. alticola), but, because of haplotype sharing, a lot of the variation was still not accounted for by Howell and Webb's (1995) proposal. Jaramillo and Burke's (1999) proposal explained the second-largest percentage of genetic variation, but their three proposed groups explained only $45 \%$ of the among-group variation. Finally, Navarro-Sigüenza and Peterson's (2004) proposal explained only $42 \%$ of the variation among their three suggested groups. In contrast, the AMOVA analysis comparing mainland northern populations to the Tres Marías Islands populations accounted for a higher percentage of the total genetic variation $(60 \%$; Table 3$)$. The $\Phi_{\mathrm{ST}}$ value was $0.68(P<0.001)$, even though there was only one fixed nucleotide difference between the two groups.

Differentiation index $\left(\Phi_{\mathrm{ST}}\right)$ values among populations generally revealed low levels of genetic differentiation. These low $\Phi_{\mathrm{ST}}$ values could be due to recent ancestry or gene flow. For calculation purposes we assumed that these values were due to gene flow, and computed the number of migrants per generation following Slatkin (1991). Many of the values suggested more than one migrant per generation or an infinite number of migrants. However, values for the Tres Marías Islands suggested these populations had less than one migrant per generation, with an average of 0.55 migrants per generation and a $\Phi_{\mathrm{ST}}$ of 0.75 , meaning that even though they shared no haplotypes with mainland populations, we cannot exclude some low level of gene flow.

The mismatch distribution for the whole species complex resulted in $\tau$ (number of generations) $=1.27, \theta_{0}$ (population size before demographic expansion) $=0$, and $\theta_{1}$ (population size after demographic expansion) $=2239$ (Fig. 4). These values show a unimodal distribution consistent with a population that has undergone a sudden demographic expansion (Rogers and Harpending 1992). The raggedness index was $0.08(P=0.13)$.

\section{DISCUSSION}

Low amounts of genetic variability in the control region sequences and the intermixing of haplotypes among Icterus pustulatus populations suggest a very recent origin of the different subspecies. The average sequence divergence among individuals was only $0.4 \%$; similar amounts of divergence have been observed in other species of the genus Icterus (Baker et al. 2003, Kondo et al. 2004).

Geographic groupings of Streak-backed Oriole individuals did not show reciprocal monophyly, a pattern that has been reported in the early stages of speciation in other species of birds (Avise et al. 1990, Baker et al. 2003, Funk and 


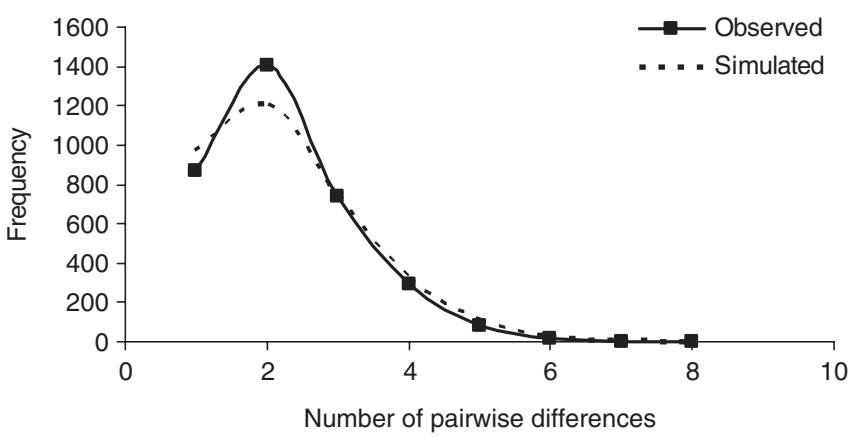

FIGURE 4. Mismatch distribution of the observed number of pairwise differences among haplotypes of the Streak-backed Oriole (Icterus pustulatus) complex. The solid line indicates the observed distribution of pairwise differences, and the dotted line indicates the simulated distribution under a model of population expansion. The observed Poisson-like distribution is consistent with a population that has undergone demographic expansion.

Omland 2003). This mtDNA polyphyly could be a consequence of incomplete lineage sorting due to insufficient time since separation or high amounts of gene flow (Seutin et al. 1993, Baker et al. 2003). Conversely, the lack of reciprocally monophyletic groups may be a result of most of the sampled subspecies not corresponding to independent histories and being only arbitrary divisions of morphological clines (Avise 1994, Zink et al. 2002).

Mitochondrial gene trees of several avian species have shown intermixing of haplotypes among populations (e.g., Song Sparrow [Melospiza melodia], Zink and Dittman 1993; Savannah Sparrow [Passerculus sandwichensis], Zink et al. 2005), suggesting many species are going through the early stages of divergence (Funk and Omland 2003). Given the low mitochondrial variation in Icterus pustulatus, the obvious plumage differences among populations may reflect different ecological and social selection pressures across the different environments in Mexico and Central America. Omland and Lanyon (2000) reported that plumage characters can evolve rapidly in orioles, which could help explain the high diversity of plumage forms found in this species. Many species of birds show variation in plumage coloration, in spite of little or no molecular variation (Greenberg et al. 1998, Baker et al. 2003, Zink et al. 2005).

\section{POPULATION HISTORY}

The distribution of Streak-backed Oriole haplotypes is consistent with a process of isolation by distance; however, the haplotypes from the $\mathrm{B}$ group in the median joining network are directly interconnected with haplotypes from the A group, rather than with those from the center (C group). This species has an uncommon phylogeographic pattern (Type III), with shallow haplotype trees showing weak geographic structure associated with recent population expansion and a lack of isolating barriers (Zink et al. 2001). Thus, the observed geographic distribution of haplotypes may be the result of recent colonization from a less widespread common ancestor without sufficient time for geographic differentiation, involving incomplete lineage sorting or reasonable amounts of gene flow. The sharing of internal ancestral haplotypes among geographically disparate localities (e.g., Nicaragua and Michoacan) strongly suggests incomplete lineage sorting due to recent divergence and range expansion (Omland et al. 2006). However, there is still uncertainty about the location of the ancestral range for this species. The mismatch analysis was consistent with a recent range and population expansion, but it is unclear whether the direction of colonization was from the north to the south or vice versa.

\section{TRES MARÍAS ISLANDS POPULATIONS}

The Tres Marías Islands populations of Icterus pustulatus (I. p. graysonii) have long been known for their morphological distinctiveness (Cassin 1867, Ridgway 1911, Howell and Webb 1995, AOU 1998, Jaramillo and Burke 1999, Navarro-Sigüenza and Peterson 2004). They are paler than individuals from the continent, almost lack streaking on the back, and seem to differ in some morphometric measurements (Jaramillo and Burke 1999). This pattern of plumage coloration, in which the continental counterpart is brighter than individuals from the islands, has been found in other birds endemic to the Tres Marías Islands (e.g., Happy Wren [Thryothorus felix], Blue Mockingbird [Melanotis caerulescens], Broad-billed Hummingbird [Cynanthus latirostris], and Cinnamon Hummingbird [Amazilia rutila]; Grant 1965). Individuals we sampled from the islands showed one fixed nucleotide substitution that separated them from all sampled continental haplotypes. This fixed difference suggests that populations from the islands have been isolated for a relatively long period of time, especially considering the low levels of mtDNA differentiation among the mainland subspecies. We did not find the island haplotype on the mainland, which is consistent with in situ mutation since island colonization; however, a recent founder event with fixation of a rare or now extinct mainland allele is also possible.

I. $p$. graysonii differs in multiple characters from the rest of the species, which argues that it could be considered a distinct unit. There are differences in mtDNA, plumage, and perhaps morphometrics and vocalizations. The phylogenetic species concept of Cracraft (1983), or the diagnosable approach, holds that a species can be recognized based on at least one diagnostic character. Based on the distinctiveness of the plumage coloration and the fixed differences in mitochondrial DNA, we recommend recognizing this taxon as a distinct species, Icterus graysonii, as proposed recently by Navarro-Sigüenza and Peterson (2004).

\section{GEOGRAPHIC PATTERN}

The most interesting result of this study is that even though the distribution of Icterus pustulatus is mostly tropical (northern Mexico to Costa Rica), the geographic pattern and haplotype 
diversity is similar to that of some temperate species (Ball et al. 1988, Greenberg et al. 1998, Milá et al. 2000, Baker et al. 2003, Kondo et al. 2004). Phenotypically, this species complex shows characteristics of a tropical species, given its geographically structured plumage variation (even though this may be clinal). The low amounts of genetic variation observed and other signatures of intermediate divergence are consistent with the earliest stages of speciation (Omland et al. 2006). It is important to emphasize that two protein coding genes (ND2 and cytochrome $b$ ) showed no variation at all when we sequenced ten of the most variable haplotypes, supporting the recent divergence of this species complex (NC-R, unpubl. data). Given that there were no definite genetic breaks in mtDNA, it is possible that the subspecies described earlier may represent only a morphological and mitochondrial DNA cline. The only fixed geographical difference we found was for the Tres Marías Islands populations. Additional morphological and behavioral work should be done to further elucidate the evolutionary history of the Tres Marías Islands populations.

\section{ACKNOWLEDGMENTS}

This research was supported by a U.S. National Science Foundation grant to KEO (DEB-0347083), a CONACyT-SEMARNAT grant to AGN-S (C01-00265), and a PAPIIT (IN 211407) grant to BEH-B. We thank students and staff at Museo de Zoología, Universidad Nacional Autonoma de México (UNAM), and other museums for collecting Streak-backed Oriole specimens. B. Kondo, J. Peters, E. Humphries, H. Vazquez, F. Jacobsen, and other students from the Omland Lab provided laboratory help and valuable comments on earlier drafts of this manuscript. We thank the following institutions for tissue loans: Marjorie Barrick Museum of Natural History, University of Nevada; Burke Museum of Natural History and Culture, University of Washington, Seattle; Peabody Museum of Natural History, Yale University; Museo de Zoología Facultad de Ciencias, Universidad Nacional Autonoma de México; and University of Kansas Natural History Museum.

\section{LITERATURE CITED}

Allen, E. S., AND K. E. OMLAND. 2003. Novel intron phylogeny supports plumage convergence in orioles (Icterus). Auk 120:961969.

American ORnithologists' UnION. 1998. Check-list of North American birds. American Ornithologists' Union, Washington, DC.

AviSE, J. C. 1994. Molecular markers, natural history and evolution. Chapman and Hall, Sunderland, MA.

Avise, J. C., C. D. AnKNey, AND W. S. Nelson. 1990. Mitochondrial gene trees and the evolutionary relationship of Mallard and Black Ducks. Evolution 44:1109-1119.

Baker, J. M., E. Lopez-Medrano, A. G. Navarro-Sigüenza, O. R. Rojas-Soto, And K. E. OMLAnd. 2003. Recent speciation in the Orchard Oriole group: divergence of Icterus spurius and Icterus spurius fuertesi. Auk 120:848-859.

Ball, R. M., S. Freeman, F. C. James, E. Bermingham, and J. C. AvISE. 1988. Phylogeographic population structure of Redwinged Blackbirds assessed by mitochondrial DNA. Proceedings of the National Academy of Sciences USA 85:1558-1562.

BANDELT, H.-J., P. ForSTER, AND A. RöHL. 1999. Median-joining networks for inferring intraspecific phylogenies. Molecular Biology and Evolution 16:37-48.
Bates, J. M., S. J. Hackett, AND J. M. Goerck. 1999. High levels of mitochondrial DNA differentiation in two lineages of antbirds (Drymophila and Hypocnemis). Auk 116:1093-1106.

CAssin, J. 1867. A third study on the Icterinae. Proceedings of the National Academy of Sciences Philadelphia 19:45-74.

CRACRAFT, J. 1983. Species concepts and speciation analysis, p. 159187. In R. F. Johnston [ED.], Current ornithology. Plenum Press, New York.

Drovetski, S. V., R. M. Zink, S. Rohwer, I. V. Fadeev, E. V. Nesterov, I. Karagodin, E. A. Koblik, and Y. A. Red'Kin. 2004. Complex biogeographic history of a Holarctic passerine. Proceedings of the Royal Society of London Series B 271:545-551.

EXCOFfier, L., G. LAVAL, AND S. SCHNEIDER [ONLINE]. 2005. Arlequin (version 3.0): an integrated software package for population genetics data analysis. Evolutionary Bioinformatics Online 1:47-50.

FriedmanN, H., L. Griscom, AND R. T. MoOre. 1950. Distributional check-list of the birds of Mexico. Part I. Pacific Coast Avifauna 29.

FunK, D. J., AND K. E. OMLAND. 2003. Species-level paraphyly and polyphyly: frequency, causes, and consequences, with insights from animal mitochondrial DNA. Annual Review of Ecology, Evolution and Systematics 34:397-423.

García-Moreno, J., A. G. Navarro-Sigüenza, A. T. Peterson, And L. A. SÁnChEZ-GonzÁLEZ. 2004. Genetic variation coincides with geographic structure in the Common Bush-Tanager (Chlorospingus ophthalmicus) complex from Mexico. Molecular Phylogenetics and Evolution 33:186-196.

Gill, F. B., B. Slikas, And D. Agro. 1999. Speciation in North American chickadees: II. Geography of mtDNA haplotypes in Poecile carolinensis. Auk 116:274-277.

Grant, P. R. 1965. Plumage and the evolution of birds on islands. Systematic Zoology 14:47-52.

Greenberg, R., P. J. Cordero, S. Droege, and R. C. Fleischer. 1998. Morphological adaptation with no mitochondrial DNA differentiation in the Coastal Plain Swamp Sparrow. Auk 115:706-712.

Hackett, S. J. 1993. Phylogenetic and biogeographic relationships in the Neotropical genus Gymnopithys (Formicaridae). Wilson Bulletin 105:301-315.

Howell, S. N. G., And S. WebB. 1995. A guide to the birds of Mexico. Oxford University Press, Oxford, UK.

Jaramillo, A., AND P. Burke. 1999. New World blackbirds: the Icterids. Princeton University Press, Princeton, NJ.

Kondo, B., J. M. BAKER, AND K. E. OMLAnd. 2004. Recent speciation between the Baltimore Oriole and the Black-backed Oriole. Condor 106:674-680.

LAWRENCE, G. N. 1872. Descriptions of new species of the genera Icterus and Synallaxis. Annals of the Lyceum of Natural History of New York 10:184-185.

Milá, B., D. J. Girman, M. Kimura, and T. B. Smith. 2000. Genetic evidence for the effect of a postglacial population expansion on the phylogeography of a North American songbird. Proceedings of the Royal Society of London Series B 267: 1033-1040.

Miller, W. D., AND L. GRiscom. 1925. Descriptions of new birds from Nicaragua. American Museum Novitates 159.

Navarro-Sigüenza, A. G., And A. T. Peterson. 2004. An alternative species taxonomy of the birds of Mexico. Biota Neotropica $4: 1-32$.

Omland, K. E., J. M. BaKer, AND J. L. Peters. 2006. Genetic signatures of intermediate divergence: population history of Old and New World Holarctic Ravens (Corvus corax). Molecular Ecology 15:795-808.

OMLAND, K. E., AND S. M. LANYON. 2000. Reconstructing plumage evolution in orioles (Icterus): repeated convergence and reversal in patterns. Evolution 54:2119-2133. 
Omland, K. E., S. M. Lanyon, And S. J. Fritz. 1999. A molecular phylogeny of the New World orioles (Icterus): the importance of dense taxon sampling. Molecular Phylogenetics and Evolution 12:224-239.

Omland, K. E., C. L. Tarr, W. I. Boarman, J. M. Marzluff, And R. C. FLEISCHER. 2000. Cryptic genetic variation and paraphyly in ravens. Proceedings of the Royal Society of London Series B 267:2472-2482.

Peters, J. 1968. Check-list of birds of the world. Museum of Comparative Zoology, Cambridge, MA.

Peterson, A. T. 1992. Phylogeny and rates of molecular evolution in the Aphelocoma jays (Corvidae). Auk 109:133-147.

PHILLIPS, A. R. 1995. The northern races of Icterus pustulatus (Icteridae), Scarlet-headed or Streaked-backed Oriole. Bulletin of the British Ornithological Council 115:98-105.

PosadA, D., AND K. A. CRANDALL. 1998. MODELTEST: testing the model of DNA substitution. Bioinformatics 14:817-818.

RidGWAY, R. 1911. The birds of North and Middle America. Smithsonian Institution, Washington, DC.

Rogers, A. R., AND H. HARPENDING. 1992. Population growth makes waves in the distribution of pairwise genetic differences. Molecular Biology and Evolution 9:552-569.

Seutin, G., J. Brawn, R. E. Ricklefs, and E. Bermingham. 1993. Genetic divergence among populations of a tropical passerine, the Streaked Saltator (Saltator albicolis). Auk 110:117-126.

SLATKIN, M. 1991. Inbreeding coefficients and coalescence times. Genetic Research 58:167-175.

Spellman, G. M., AND J. Klicka. 2007. Phylogeography of the White-breasted Nuthatch (Sitta carolinensis): diversification in North American pine and oak woodlands. Molecular Ecology 16:1729-1740.

Spellman, G. M., B. Riddle, And J. Klicka. 2007. Phylogeography of the Mountain Chickadee (Poecile gambeli): diversification, introgression, and expansion in response to Quaternary climate change. Molecular Ecology 16:1055-1068.

SwOFFORD, D. L. 1999. PAUP*: phylogenetic analysis using parsimony (* and other methods). Version 4.010b. Sinauer Associates, Sunderland, MA.

TARR, C. L. 1995. Primers for amplification and determination of mitochondrial control-region sequences in oscine passerines. Molecular Ecology 4:527-529.

Tobias, J. A., J. M. Bates, S. J. Hackett, And N. Seddon. 2008. Comment on "The latitudinal gradient in recent speciation and extinction rates of birds and mammals." Science 319:901902.

VAn Rossem, A. J. 1927. A new race of the Sclater Oriole. Condor 29:76-77.

Wagler, J. G. 1829. Beyträge und Bemerkunger zu dem ersten Bande seines System Avium. Isis von Oken 22:755.

Weir, J. T., AND D. Schluter. 2007. The latitudinal gradient in recent speciation and extinction rates of birds and mammals. Science 315:1574-1576.

Zink, R. M., AND D. L. Dittmann. 1993. Gene flow, refugia and evolution of geographic variation in the Song Sparrow (Melospiza melodia). Evolution 47:717-729.

Zink, R. M., A. E. Kessen, T. V. Line, and R. C. Blackwell-Rago. 2001. Comparative phylogeography of some aridland bird species. Condor 103:1-10.

Zink, R. M., J. D. Rising, S. Mockford, A. G. Horn, J. M. Wright, M. Leonard, And M. C. Westberg. 2005. Mitochondrial DNA variation, species limits, and rapid evolution of plumage coloration and size in the Savannah Sparrow. Condor 107:21-28.

Zink, R. M., S. Rohwer, S. Drovetski, R. C. Blackwell-Rago, AND S. L. FARRELL. 2002. Holarctic phylogeography and species limits of Three-toed Woodpeckers. Condor 104:167-170. 
APPENDIX. Specimens of Icterus pustulatus $(n=102)$ sequenced for the mtDNA control region gene in this project, showing country, state (or department, abbreviated as “Dpto."), and locality of sampling, and catalog number. Acronyms are: FMNH = Field Museum of Natural History; KU = Museum of Natural History, University of Kansas; MBM = Marjory Barrick Museum, University of Nevada, Las Vegas; MZFC = Museo de Zoologia "Alfonso Herrera" Facultad de Ciencias, Universidad Nacional Autónoma de México; UWBM = University of Washington Burke Museum of Natural History and Culture; and YPM = Yale Peabody Museum. Tissues without a voucher skin specimen show only the field reference number.

\begin{tabular}{|c|c|c|c|c|}
\hline Country & $\begin{array}{l}\text { State or } \\
\text { Department }\end{array}$ & Locality & $\begin{array}{l}\text { Voucher } \\
\text { Catalog Number }\end{array}$ & $\begin{array}{l}\text { GenBank } \\
\text { Number }\end{array}$ \\
\hline El Salvador & $\mathrm{LaPaz}$ & Cantón Animas Abajo & KU 9274 & FJ410878 \\
\hline El Salvador & $\mathrm{LaPaz}$ & Cantón Animas Abajo & KU 9277 & FJ410879 \\
\hline El Salvador & $\mathrm{LaPaz}$ & Zacatecoluca & KU 9275 & FJ410873 \\
\hline El Salvador & $\mathrm{La} \mathrm{Paz}$ & Zacatecoluca & KU 9524 & FJ410874 \\
\hline El Salvador & El Sonsonate & Cruz Grande & KU 6005 & FJ410875 \\
\hline El Salvador & El Sonsonate & Cruz Grande & KU 6001 & FJ410872 \\
\hline El Salvador & San Vicente & San Vicente & KU 7691 & FJ410876 \\
\hline El Salvador & San Vicente & San Vicente & KU 7693 & FJ410877 \\
\hline El Salvador & San Miguel & Volcán de San Miguel & YPM 100371 & FJ410871 \\
\hline Honduras & Copán & Copan, Ruinas & MBM 7147 & FJ410824 \\
\hline Honduras & Copán & Copan, Ruinas & MBM 7146 & FJ410823 \\
\hline Honduras & Copán & Copan, Ruinas & MBM 7737 & FJ410825 \\
\hline Honduras & Copán & Copan, Ruinas & MBM 7762 & FJ410826 \\
\hline Honduras & Copán & Copan, Ruinas & MBM 7763 & FJ410827 \\
\hline Nicaragua & De Rivas & La Flor & UWBM 69072 & FJ410854 \\
\hline México & Chiapas & Ocozocuautla & UWBM 52129 & FJ410807 \\
\hline México & Chiapas & Ocozocuautla & UWBM 52133 & FJ410808 \\
\hline México & Chiapas & Rancho Bellavista Tonalá & MZFC 19431 & FJ410802 \\
\hline México & Chiapas & Rancho Bellavista Tonalá & MZFC 19430 & FJ410804 \\
\hline México & Chiapas & Rancho Bellavista Tonalá & MZFC 19432 & FJ410803 \\
\hline México & Chiapas & Tuxtla Gutiérrez & KEO 10 & FJ410806 \\
\hline México & Chiapas & Tuxtla Gutiérrez & MZFC 13569 & FJ410805 \\
\hline México & Colima & Laguna la María & MZFC 16347 & FJ410810 \\
\hline México & Colima & Laguna la María & MZFC 16346 & FJ410809 \\
\hline México & Guerrero & $2 \mathrm{~km} \mathrm{NE}$ of El Carmen & MZFC 16535 & FJ410821 \\
\hline México & Guerrero & $2 \mathrm{~km} \mathrm{NE}$ of El Carmen & MZFC 16536 & FJ410822 \\
\hline México & Guerrero & $2 \mathrm{~km} \mathrm{NE}$ of El Carmen & MZFC 16534 & FJ410820 \\
\hline México & Guerrero & Laguna Nuxco & MZFC 16352 & FJ410819 \\
\hline México & Guerrero & Los Cirulos Petatlan & MZFC 19426 & FJ410818 \\
\hline México & Guerrero & Los Cirulos Petatlan & MZFC 19425 & FJ410817 \\
\hline México & Guerrero & San Miguel Tecuiciapan & MZFC 18969 & FJ410815 \\
\hline México & Guerrero & San Miguel Tecuiciapan & MZFC 18968 & FJ410813 \\
\hline México & Guerrero & San Miguel Tecuiciapan & MZFC 18998 & FJ410811 \\
\hline México & Guerrero & San Miguel Tecuiciapan & MZFC 18970 & FJ410812 \\
\hline México & Guerrero & San Miguel Tecuiciapan & MZFC 19005 & FJ410814 \\
\hline México & Guerrero & San Miguel Tecuiciapan & MZFC 18974 & FJ410816 \\
\hline México & Jalisco & $3 \mathrm{~km} E$ of Chapala & MZFC 15558 & FJ410834 \\
\hline México & Jalisco & $3 \mathrm{~km}$ E of Chapala & MZFC 15559 & FJ410833 \\
\hline México & Jalisco & Emiliano Zapata & JAL 2 & FJ410830 \\
\hline México & Jalisco & Emiliano Zapata & JAL 3 & FJ410831 \\
\hline México & Jalisco & Emiliano Zapata & JAL 4 & FJ410832 \\
\hline México & Michoacán & Las Haciendas & MZFC 16353 & FJ410840 \\
\hline México & Michoacán & Presa Infiernillo & MZFC 16483 & FJ410838 \\
\hline México & Michoacán & Presa Infiernillo & MZFC 16485 & FJ410836 \\
\hline México & Michoacán & Presa Infiernillo & MZFC 16482 & FJ410835 \\
\hline México & Michoacán & Presa Infiernillo & MZFC 16486 & FJ410839 \\
\hline México & Michoacán & Presa Infiernillo & MZFC 16484 & FJ410837 \\
\hline México & Morelos & Huautla & MZFC 13560 & FJ410842 \\
\hline México & Morelos & Limón & P 01 & FJ410843 \\
\hline México & Morelos & Limón & P 02 & FJ410844 \\
\hline México & Morelos & Limón & $\mathrm{P} 03$ & FJ410845 \\
\hline México & Morelos & Puente de Ixtla & MZFC 13744 & FJ410841 \\
\hline
\end{tabular}


APPENDIX. (Continued).

\begin{tabular}{|c|c|c|c|c|}
\hline Country & $\begin{array}{l}\text { State or } \\
\text { Department }\end{array}$ & Locality & $\begin{array}{l}\text { Voucher } \\
\text { Catalog Number }\end{array}$ & $\begin{array}{l}\text { GenBank } \\
\text { Number }\end{array}$ \\
\hline México & Morelos & Yautepec & PEP 1485 & FJ410847 \\
\hline México & Morelos & Yautepec & MZFC 6797 & FJ410846 \\
\hline México & Nayarit & Isla María Madre & MZFC 19224 & FJ410891 \\
\hline México & Nayarit & Isla María Madre & MZFC 19225 & FJ410890 \\
\hline México & Nayarit & Isla María Madre & MZFC 19226 & FJ410896 \\
\hline México & Nayarit & Isla María Madre & MZFC 19227 & FJ410897 \\
\hline México & Nayarit & Isla María Madre & MZFC 19228 & FJ410898 \\
\hline México & Nayarit & Isla María Madre & MZFC 19229 & FJ410899 \\
\hline México & Nayarit & Isla María Magdalena & MZFC 19221 & FJ410888 \\
\hline México & Nayarit & Isla María Magdalena & MZFC 19222 & FJ410895 \\
\hline México & Nayarit & Isla María Magdalena & MZFC 19232 & FJ410892 \\
\hline México & Nayarit & Isla María Magdalena & MZFC 19223 & FJ410894 \\
\hline México & Nayarit & Isla María Magdalena & MZFC 19233 & FJ410893 \\
\hline México & Nayarit & Isla María Magdalena & MZFC 19234 & FJ410887 \\
\hline México & Nayarit & Isla María Magdalena & MZFC 19235 & FJ410889 \\
\hline México & Nayarit & San Blas & MZFC 15546 & FJ410853 \\
\hline México & Nayarit & San Blas & MZFC 15557 & FJ410848 \\
\hline México & Nayarit & San Blas & MZFC 15545 & FJ410852 \\
\hline México & Nayarit & San Blas & MZFC 15556 & FJ410849 \\
\hline México & Nayarit & San Blas & MZFC 15555 & FJ410850 \\
\hline México & Nayarit & San Blas & MZFC 15544 & FJ410851 \\
\hline México & Nayarit & Tepic & MZFC 19660 & FJ410905 \\
\hline México & Oaxaca & Cerro Piedra Larga & MZFC 12406 & FJ410864 \\
\hline México & Oaxaca & Cerro Piedra Larga & MZFC 12408 & FJ410863 \\
\hline México & Oaxaca & Cerro Piedra Larga & MZFC 18696 & FJ410861 \\
\hline México & Oaxaca & Cerro Piedra Larga & MZFC 18706 & FJ410860 \\
\hline México & Oaxaca & Cerro Piedra Larga & MZFC 18702 & FJ410859 \\
\hline México & Oaxaca & Cerro Piedra Larga & MZFC 18704 & FJ410862 \\
\hline México & Oaxaca & Nizanda, C. al Aguaje & MZFC 16906 & FJ410857 \\
\hline México & Oaxaca & Nizanda, Enclave1 & Conacyt 1265 & FJ410855 \\
\hline México & Oaxaca & Nizanda, Enclavel & Conacyt 1293 & FJ410856 \\
\hline México & Oaxaca & Rancho Las Minas & MZFC 19433 & FJ410858 \\
\hline México & Oaxaca & San Pedro Tepanatepec & UWBM 52181 & FJ410865 \\
\hline México & Oaxaca & San Pedro Tepanatepec & UWBM 52182 & FJ410866 \\
\hline México & Oaxaca & San Pedro Tepanatepec & UWBM 52193 & FJ410867 \\
\hline México & Puebla & Venta Salada & MZFC 11132 & FJ410868 \\
\hline México & Puebla & Venta Salada & MZFC 11131 & FJ410869 \\
\hline México & Puebla & Venta Salada & MZFC 11134 & FJ410870 \\
\hline México & Sinaloa & Copala & MZFC 15392 & FJ410881 \\
\hline México & Sinaloa & Copala & MZFC 15393 & FJ410884 \\
\hline México & Sinaloa & Copala & MZFC 15391 & FJ410883 \\
\hline México & Sinaloa & Copala & MZFC 15394 & FJ410882 \\
\hline México & Sinaloa & Cosalá & UWBM 81439 & FJ410902 \\
\hline México & Sinaloa & Cosalá & MZFC 19712 & FJ410904 \\
\hline México & Sinaloa & Cosalá & MZFC 19719 & FJ410903 \\
\hline México & Sinaloa & El Limón & MZFC 19710 & FJ410900 \\
\hline México & Sinaloa & El Limón & UWBM 81433 & FJ410901 \\
\hline México & Sinaloa & $2 \mathrm{~km} \mathrm{~W}$ of El Magistral & MZFC 15395 & FJ410880 \\
\hline México & Sonora & Isla Tiburón, El Caracol & MZFC 14967 & FJ410885 \\
\hline México & Zacatecas & Jalpa & MZFC 15818 & FJ410886 \\
\hline
\end{tabular}

